\title{
Landmark ruling on whaling from the International Court of Justice
}

$\mathrm{O}$ n 31 March 2014, the International Court of Justice (ICJ) ruled that Japan's whaling activities in Antarctica did not comply with Article VIII of the International Convention for the Regulation of Whaling (ICRW), which permits whaling for scientific purposes. Copious and confusing media commentary followed the decision. This included seemingly conflicting reports from within Japan, which initially indicated whole-hearted compliance with the ruling, which required this whaling to cease, but later suggested that implementation by Japan might be limited to a brief halt followed by a launch of a new Antarctic 'research' programme including lethal take.

Concerns about the sustainability of whaling in the southern hemisphere can be traced back to comments in the 1880s from Sir William Henry Flower, Director of the Natural History Units of the British Museum. Nonetheless, by 1911, whaling had grown rapidly and without controls in the Southern Ocean and, in response, the British Colonial Office and the Museum sent unsung hero, Major G.E.H. Barret Hamilton to South Georgia to investigate. Sadly, he died there in January 1914, but not before preparing the first report to try to apply scientific assessment to high seas whaling. Much later, in 1946, after various failed efforts to manage stocks and moderate international competition, the ICRW was concluded and the International Whaling Commission (IWC) formed. In 1979, the IWC established the Southern Ocean Sanctuary (intended to be a 'no whaling zone') and, in 1986, the moratorium came into effect. However, IWC members could still legally kill whales in three ways; firstly, this could be done by those IWC Parties which had legally objected to the moratorium (including, initially, Japan although it later withdrew its objection); secondly, via the 'aboriginal subsistence whaling' clause (permitting certain indigenous people with a longstanding nutritional and cultural dependence on whales to take an IWC-agreed quota); and finally as 'Article VIII' whaling - a clause originally envisaged as a means of taking whales for pressing scientific investigation, but which allows countries to set their own research quotas.

The case against Japan at the ICJ was brought by Australia (with New Zealand 'intervening'). The proceedings were heard in June and July 2013 and are archived on the ICJ website. At the core of Australia's argument was that Japan's ongoing programme, known as JARPAII, was not scientific but commercial in purpose. Much was made of what did, and did not, constitute science. However, the court largely side-stepped this in its ruling, concluding that although Japan's aims were 'broadly scientific', there was a lack of justification for large scale 'sampling', especially for the annual quota of 850 (plus or minus 10\%) Antarctic minke whales. The court also noted the open-ended time frame for JARPAII, its very limited scientific outputs to date and its failure to consider non-lethal alternatives to killing whales for research.

These observations by the ICJ not only provided the foundation for finding that JARPAII was illegal but also established, with all its authority, issues that should be taken in account in other whale killing intending to be covered by Article VIII.

Despite the ruling, the costs of whaling and the declining enthusiasm for whale meat, pro-whaling interests appear to be prevailing in Japan. It appears that a revised Antarctic whaling programme will be developed next year and, interestingly, Japan has already made some small changes to quotas for its ongoing North Pacific hunt, which is also conducted under Article VIII. However, a narrow, ineffective response to the ruling could have serious implications beyond whaling issues given the ICJ's inevitably increasing role in disputes between countries over other natural resources on our rapidly changing planet.

Mark Peter Simmonds 